\title{
A árvore da liberdade nagô: Marcos Theodoro Pimentel e sua família entre a escravidão e o pós-Abolição. Itaparica, 1834-1968
}

The Nago Tree of Freedom: Marcos Theodoro Pimentel and his Family between Slavery and Post-Abolition. Itaparica, 1834-1968

Wellington Castellucci Junior*

\section{Resumo}

Este artigo aborda a trajetória de três gerações da família Pimentel, desde a chegada ao Brasil do africano Marcos, no final da década de 1830, até o advento da sacerdotisa Ondina Valéria Pimentel, quarta líder espiritual do candomblé Ilê Axé Opô Afonjá, no ano de 1968. O uso de variada documentação existente nos arquivos nacionais e internacionais permitiu compor a genealogia de uma família que permaneceu unida durante toda a segunda metade do século XIX e até as últimas décadas do século XX, sendo Marcos o responsável pela fundação do culto de tradição nagô aos egunguns na Ilha de Itaparica. O artigo também aborda os enfrentamentos judiciais de Marcos para defender os interesses de seus aliados e a relação entre ele e seus filhos.

Palavras-chave: escravidão; família; liberdade.

\section{Abstract}

This article deals with the trajectory of three generations of the Pimentel family, starting with the arrival in Brazil of the African Marcos in the late 1830s until the advent of the priestess Ondina Valéria Pimentel, the fourth spiritual leader of the Candomble temple Ilê Axé Opô Afonjá, in the year 1968. The use of varied documentation in national and international archives made possible the reconstruction of the genealogy of a family that remained united throughout the second half of the 19th century until the last decades of the 20th century, being Marcos responsible for the foundation of the Nago cult of the Egunguns on the Island of Itaparica, in Bahia. The article also addresses Marcos' judicial confrontations to defend the interests of his allies and the relationship between him and his children.

Keywords: slavery; family; freedom.

\footnotetext{
* Universidade Federal do Recôncavo da Bahia (UFRB), Centro de Artes, Humanidades e Letras. Cachoeira, BA, Brasil. wcastelluccijunior@gmail.com <https://orcid.org/0000-0002-8169-5611>
} 
Em 19 de março de 1975 faleceu aos 59 anos, em Salvador, Bahia, Ondina Valéria Pimentel, sacerdotisa do Ilê Axé Opô Afonjá, terreiro de candomblé baiano de nação Ketu. Ialorixá, condecorada com a medalha de "Chevalier de l'Ordre du Mérite du Sénégal”, ${ }^{1}$ Mãezinha, como era conhecida, foi a quarta sacerdotisa que esteve à frente do Axé Afonjá, sucedendo à Mãe Senhora, filha de santo da fundadora daquele terreiro, surgido em 1910 (Costa Lima, 2003; Castillo, 2012).

Até falecer, Ondina cumpria as obrigações naquele terreiro e na casa AbaIlê ou Oba-Ilê, fundada por ela no Rio de Janeiro, sendo apoiada por figuras de proa, como Deoscóredes Maximiliano dos Santos (Mestre Didi), filho de Senhora, e Arsênio Ferreira dos Santos. Eles foram responsáveis pela afirmação da cultura afro-brasileira, particularmente de vertente nagô (Luz, 2002, p.81).

A vida de Ondina Pimentel e a de suas antecessoras, assim como a história do Axé Opô Afonjá, têm sido estudadas por historiadores e antropólogos, sendo a obra de Mestre Didi um de seus ícones (Santos, 1988; Costa Lima, 2004; Braga, 1995; Carneiro, 1986). Conforme essas pesquisas, Ondina pertenceu à linhagem de um proeminente africano que chegou à ilha de Itaparica como escravo e, quando liberto, tornou-se famoso pelos gestos de solidariedade e pela projeção econômica. Batizado em Itaparica como Marcos, ele aparece na literatura sobre temas relacionados à história do Candomblé na Bahia, em particular do Opô Afonjá e como fundador do culto aos egunguns em Itaparica (Costa Lima, 1976; Castillo, 2012).

Com o intuito de contribuir para os estudos sobre a história de escravos e libertos na Bahia do século XIX e a vida dos negros no pós-Abolição, este artigo analisa a trajetória de membros de três gerações da linhagem de Marcos que se tornaram conhecidos no Brasil ao longo de mais de um século, sendo aquele africano a pedra angular desta narrativa.

Aqui, metaforicamente, tomamos Marcos como o tronco familiar, o patriarca da árvore genealógica nagô. Os seus filhos, Marcos Cardoso, José Theodoro Pimentel e Flora da Trindade Pimentel são os galhos frondosos dessa alegórica árvore. Os netos, Ondina e seus irmãos, são os frutos que continuam a germinar e a semear a cultura nagô pelas cidades brasileiras. Além desses sujeitos, as africanas Maria Cardoso e Raquel, mulheres de Marcos e que lhe deram filhos, têm presença assegurada no curso desta história.

Como veremos, Marcos e as gerações seguintes construíram redes de sociabilidade e fundaram espaços religiosos de tradição nagô no Brasil. A constituição da família de sangue, o reconhecimento do parentesco, a formalização de laços de amizade e de compadrio formaram a base, sobre a qual foram 
sedimentadas relações de hierarquias e práticas de alianças forjadas por Marcos. Elas deram contornos a uma comunidade de africanos no século XIX, que seguiu em frente no século seguinte com seus descendentes.

\section{MARCOS: O SÓLIDO TRONCO FAMILIAR}

O avô de Ondina Valéria Pimentel chegou ao Brasil por volta de 1833, ou poucos antes, quando as pressões para a proibição do tráfico aumentavam na mesma proporção em que este se intensificava. Seu primeiro registro em terras brasileiras, de que se tem notícia, é o batismo em Itaparica, na Matriz do Santíssimo Sacramento, em 26 de dezembro de $1834 .^{2}$

Capturado na África, transladado pelo Atlântico e escravizado no Brasil, Marcos era nagô e viveu cativo em Itaparica por aproximadamente 15 anos. Teria sido vítima da guerra santa iniciada na África em 1808 por Usuman Dan Fodio, que formou o Califado de Sokoto e assolou toda a região da Costa da Mina? (Reis, 2014). Ou teria sido capturado durante outras guerras ocorridas na região da Iorubalândia, as quais resultaram na escravização de várias pessoas, muitas delas conduzidas para o litoral, embarcadas em Onim (como a cidade de Lagos era conhecida) e trasladadas para o Brasil e Cuba? (Castillo, 2017, p.11-13). Infelizmente, a sua vida pregressa ainda é uma incógnita.

Sua chegada ao Brasil ocorre, portanto, numa conjuntura de combate ao tráfico, pelos ingleses, e quando Lagos assumia, a partir de 1830, a primazia como porto de embarque de cativos na Costa dos Escravos, no Golfo de Benin. Isso talvez explique a sua obstinação em realizar, no fim da vida, a viagem àquele lugar ao lado de seu filho e de mais gente, no início da década de 1880 .

Nas décadas finais do tráfico negreiro, negociantes de "carne humana" e senhores escravistas importaram a maior quantidade possível de africanos antes da extinção desse comércio. Uma avaliação parcial da quantidade de africanos desembarcados em Itaparica é apreciada pelo número de batismos nas suas três freguesias, correspondentes ao período de 1798 a 1865. Segundo tais registros, foram batizados na Ilha 2.009 africanos, sendo 627 mulheres e 1.382 homens. ${ }^{3}$ Durante todo o período, o número de homens foi superior ao de mulheres, exceto em Santo Amaro do Catu, quando, na primeira metade do século XIX, elas lideraram a contabilidade.

A maior parte dos batizados foi registrada como africana, mas quando os párocos citaram as "nações", foram os jeje (135) e os nagô (120) os mais frequentes, além de mina, calabar, cabinda e outros. A maior quantidade de africanos oriundos da região da Costa da Mina desembarcados ali coincide com 
as referências feitas nos registros de viagens realizadas por traficantes de Itaparica. Um deles fez 11 viagens atlânticas, embarcando 3.037 africanos, chegando ao Brasil 2.845 sujeitos, segundo o Trans-Atlantic Slave Trade: a Database (TSTD). ${ }^{4}$

Os números dos africanos ficam mais interessantes quando se analisam os batismos do período anterior à proibição do tráfico e os realizados pós-1831. Segundo os livros de assentos, foram batizados, entre 1798 e 1831, 1.655 africanos, enquanto 444 indivíduos receberam o batismo de 1832 até 1865 . Considerando os batizados dos chamados nacionais - pardos, brancos e crioulos - para os dois períodos, foram 6.125 indivíduos até 1831, e 3.487 entre 1832 e o final dos anos 1850, totalizando 9.612 sujeitos.

Ou seja, até 1831, o percentual de africanos batizados correspondeu a aproximadamente $26,53 \%$ da totalidade. E, após essas décadas, ele despencou para $12,73 \%$ do total. Coincidentemente, os números relativos aos nacionais batizados estão próximos daqueles relatados por uma autoridade policial no ano de 1848, quando apontou 7.382 livres residentes em Itaparica (3.441 homens e 3.941 mulheres). ${ }^{5}$

Já em relação aos africanos, como se observa, a queda expressiva dos batismos pode estar associada ao final do tráfico negreiro após 1831. Porém, os números, ainda que menores, sugerem que o tráfico continuou clandestinamente, pois Itaparica seguiu como área de desembarque de africanos após a proibição daquele comércio. Em 29 de outubro de 1835, um correspondente escreveu à Presidência da Província relatando o desembarque de africanos "angola" em Itaparica feito por dois portugueses, residentes em Salvador. Segundo ele, "não há aqui quem não tenha o seu escravo novo, e dos quais o juiz de paz desta ilha José Ferreira de Oliveira e Silva, mandou ao antecessor de V. Ex um moleque ainda com a tanga com que saltou". ${ }^{6}$

As operações clandestinas não pararam em 1835, pois outro desembarque ocorreu bem mais tarde, desta feita por uma escuna chamada Relâmpago, em 1851 (Rodrigues, 2000). ${ }^{7}$ O tráfico seguiu após 1831 porque possuía capilaridades no próprio sistema de governo, e, como categorizou Chalhoub, porque contou com a "conivência e a corrupção de autoridades públicas e com o apoio de setores diversos da população" (Chalhoub, 2012, p.36).

Parte dos africanos ali desembarcados seguia para as lavouras do Recôncavo, para o sul, como consta no processo da escuna Relâmpago. Mas, provavelmente, uma parte permaneceu em Itaparica para ser utilizada nos trabalhos de roça, na pesca e, principalmente, nas armações de caça de baleia. Em 1 de outubro de 1847, por exemplo, foram batizados na Matriz de Itaparica 
12 africanos, na maioria homens, pertencentes à armação de baleia situada no Manguinho, distrito da vila de Itaparica. ${ }^{8}$

Foi nessa conjuntura de proibição do tráfico atlântico que Marcos chegou ao Brasil. Poderia ser africano livre, mas ele jamais reivindicou a sua liberdade sob esta alegação. Sua atitude pode ser explicada pelas péssimas condições de vida a que eram submetidos os africanos livres, sob a guarda de autoridades provinciais, repartições públicas e de particulares (Florence, 1989; Conrad, 1978). É importante considerar a conjuntura extremamente adversa, sobretudo após as revoltas escravas ocorridas na Bahia em 1807 e 1835, que criaram um ambiente desfavorável, silenciando os africanos. No contexto em que se discutia no parlamento o que se fazer com os africanos livres, era mais prudente negociar em vez de se envolver com autoridades e, quem sabe, fazer uma transição de apátrida para liberto (Mamigonian, 2015).

Durante a escravidão, Marcos desempenhou o ofício de barbeiro, profissão medieval europeia e bastante difundida na África, inclusive na região onde, provavelmente, ele viveu e foi embarcado. Era tão importante que, em 1808, ainda havia um último órgão no Rio de Janeiro, responsável pela regulamentação, fiscalização e emissão de cartas destinadas àqueles que atuavam nas diversas atividades relacionadas às práticas médicas em Portugal e em seus domínios (Jeha, 2017, p.3; Pimenta, 1998, p.351).

$\mathrm{Na}$ Bahia, barbeiros sangradores e músicos, muitos dos quais eram africanos, figuraram como personalidades prósperas e com grande potencial de ascensão social após a libertação do cativeiro. Nicolau Parès identificou até mesmo um homônimo de Marcos que, além do citado ofício, tocava em uma banda musical, cuja atuação na festa do Bonfim, em janeiro de 1866, animou muita gente e lhe rendeu dinheiro (Parès, 2014, p.17). ${ }^{9}$ Barbeiro era um ofício que estabelecia grau de diferenciação entre este e os demais escravizados. A sua especialização conferia, consequentemente, ganhos financeiros e poder de barganhar a sua alforria juntos aos senhores (Castillo, 2017). Esse ofício permitiu, certamente, a Marcos acumular dinheiro e comprar a liberdade em 1849. Consta na carta de alforria, escrita pela viúva do inventariado, que Marcos pagou a "quantia de novecentos mil reis, que do mesmo recebi ao passar esta, podendo assim gozar de plena liberdade, como se livre nascesse com todas as demais cláusulas úteis de direito". ${ }^{10}$

A liberdade de Marcos esteve na média dos preços pagos por escravos africanos com alguma qualificação, que compraram suas liberdades durante a década de 1840, em Itaparica. ${ }^{11}$ Uma década após sua emancipação, os preços subiriam. O africano Pedro, por exemplo, ofício de tanoeiro, ocupação 
valorizada no mercado de escravos numa vila de pescadores e caçadores de baleia, comprou a sua alforria por \$1:500,000 réis e mais o compromisso de prestar serviços ao seu senhor por mais um ano. ${ }^{12}$

Considerando os valores médios pagos pelos cativos urbanos alforriados em Salvador no mesmo período, nota-se que o custo da liberdade de Marcos esteve bem acima daqueles praticados na capital. Kátia Mattoso apontou o valor aproximado de 543\$000 reis para um escravo adulto e com boas condições de saúde. Além de enfrentar uma conjuntura de fechamento do tráfico e do aumento da demanda europeia por produtos resultantes da mão de obra escrava, certamente o seu grau de especialização pesou na compra da liberdade (Mattoso, 1988, p.67).

A vida em cativeiro não impediu que Marcos investisse em sonhos e objetivos. Em sua trajetória, algumas instituições foram relevantes para a afirmação de sua identidade e a dos seus conterrâneos: família, relações afetivas e amizade comercial. A família nuclear foi importante para formalizar laços de compadrio e, assim, ele atraiu para perto de si outros africanos. Após adquirir a liberdade, passou a se chamar Marcos Theodoro Pimentel, incorporando o sobrenome do seu ex-senhor. Mais tarde, tornar-se-ia conhecido por Marcos velho.

Em algumas situações, adotar sobrenome senhorial, quando libertos, representou a possibilidade de eles carregarem consigo um pouco do prestígio do ex-senhor, de sua identidade e de suas relações sociais, heranças imateriais, como afirmou Roberto Guedes Ferreira (Ferreira, 2011, p.246-247). Esses seriam mecanismos de reinserção social de alguns negros no mundo dos brancos, forma de diferenciar-se de outros libertos sem vínculos mais sólidos com membros da elite local, além das possibilidades de ascensão social. Parece provável, também, que Marcos postulou o sobrenome de seus antigos senhores com a intenção de compor a sua linhagem em terras brasileiras, uma vez que a africana havia sido perdida durante a travessia do Atlântico.

Assim, pois, ao incorporar o sobrenome senhorial após a liberdade, Marcos garantiu, com base no sobrenome, sua descendência, de modo que todos soubessem dos seus laços de parentesco construídos ainda no cativeiro e solidificados em liberdade, princípio fundamental para afirmação de sua identidade, inclusive para afirmar a sua paternidade. Graças à adoção desse procedimento, acompanhamos a trajetória da sua família, desde a sua chegada, passando por Ondina Valéria Pimentel e seguindo em frente. Sobrenome senhorial foi o fio condutor para a identificação do parentesco de sangue e a origem parental, por conseguinte, consolidação da família liberta. 
Depois de alforriado, provavelmente, Marcos abdicou do ofício de barbeiro. Em nenhum documento relativo à época de alforriado há uma só referência à sua profissão do cativeiro. Isso pode estar relacionado à perda de prestígio dos barbeiros após os anos 1830, quando foram introduzidas medidas legislativas que visavam restringir aos médicos e cirurgiões as práticas de cura antes realizadas por barbeiros, assim reduzindo o seu campo de atuação e possibilidade de renda (Pimenta, 1998).

As fontes sugerem que ele passou a caçar e comercializar derivados de baleias, pois encontrou na Ilha o terreno fértil para expandir tal negócio. No século XIX, Itaparica era um dos locais da Bahia onde funcionavam armações de caça de baleias para a produção do óleo extraído da gordura animal. Esse produto, além de exportado, destinava-se ao abastecimento de Salvador e Recôncavo baiano, e a carne do animal era consumida por escravos e pelos pobres (Castellucci Junior, 2005).

Quatro anos após se tornar liberto, Marcos resgatou do cativeiro o seu primeiro filho havido com a africana Maria, escrava de uma fazenda próxima na qual ele vivera como cativo, ambas vizinhas à vila de Itaparica. Ele pagou 150 mil-réis pela liberdade do filho a José Estevão Cardoso, também senhor da genitora da criança. ${ }^{13}$ Aquele seria o seu eterno parceiro, futuro sócio nos negócios da baleia, e daria sequência aos cultos aos eguns em Itaparica.

Embora tivesse libertado o seu primogênito, não foi naquele momento que Marcos Theodoro Pimentel assumiu a sua relação paternal com a criança. Também não viveria maritalmente com a mãe dele, afirmaria mais tarde Marcos, o qual ficaria conhecido como o jovem, denominação conferida àquele para diferenciá-lo do pai, o velho. Mais adiante, como fizera o seu genitor, Marcos jovem incorporaria o sobrenome do seu ex-senhor, associando-o ao do pai, passando então a se chamar Marcos Cardoso Pimentel.

No livro de batismo de Itaparica constam como padrinhos de Marcos jovem, em 13 de março de 1853, dois homens, cujo status civil e jurídico desconhecemos. Eles, aparentemente, não fizeram parte do círculo de relações comerciais e de amizade de Marcos velho nas décadas seguintes. ${ }^{14}$ Quais as motivações dessa escolha? Não sabemos, mas uma das possibilidades é que a condição de liberto do menino Marcos, cuja carta de alforria foi apresentada na pia batismal, tenha concorrido para a escolha de pessoas sem preocupação maior com um compromisso de libertá-lo no futuro.

Após esse evento, temos poucas pistas de Marcos velho, mas na década de 1860 coisas importantes ocorreram. Nessa época, já há evidências de que Marcos velho iniciara uma relação de amizade com um conterrâneo nagô que 
chegara muito antes dele a Itaparica. Batizado com o nome de José no ano de $1816,{ }^{15}$ após a liberdade ele também incorporaria o sobrenome senhorial, passando a se chamar José Severo Martins Braga. Em algum momento, ele também se envolveu em negócios da baleia, tornando-se, além de amigo, futuro sócio dos dois Marcos para o resto de suas vidas, como veremos.

Mais do que isso, em 10 de janeiro de 1865 José Severo Martins Braga batizaria a menina Flora, fruto do segundo relacionamento de Marcos velho, com a africana Raquel. ${ }^{16}$ Nessa época, ambas ainda viviam no cativeiro, mas quando Marcos velho fez o seu testamento, em 1881, elas já eram forras, e, embora não tenhamos comprovações documentais, suspeitamos de que José tenha contribuído para a liberdade, ao menos, da menina Flora.

Em sua vida pregressa, José já havia batizado outros africanos, quando era cativo, exercendo influência hierárquica no universo da escravidão, sobretudo entre os africanos. Entre janeiro de 1834 e novembro de 1835, ele apadrinhou duas mulheres e dois homens, todos africanos. Outro afilhado apareceu ao longo de sua trajetória, e especificamente dois deles foram amparados em suas verbas testamentárias, como veremos à frente (Castellucci Junior, 2014).

Nota-se outra conotação na relação de compadrio entre Marcos e José, no caso de Flora. Havia uma relação de cumplicidade, e o primeiro sabia perfeitamente da inserção do segundo no universo do cativeiro. Ao escolher seu parceiro para apadrinhar a filha Flora, Marcos coroou simbolicamente os laços de amizade que jamais se romperiam enquanto estivessem vivos. Provavelmente, também projetou, em curto prazo, a alforria da filha e da companheira, com a qual já tinha outro filho por nome José Theodoro Pimentel, cujo assento de batismo não encontramos.

Não sabemos, com exatidão, quando esses dois africanos começaram a caçar baleias para comercializar os seus derivados e o óleo extraído da sua gordura. Mas foi com base nessa atividade produtiva, historicamente de suma importância para a economia colonial, que eles se tornaram sujeitos endinheirados e influentes entre os libertos e alguns livres na Ilha. À época em que os dois começaram a despontar como comerciantes desse negócio, as armações de baleias, instaladas em Itaparica desde a época colonial, estavam fechando. Era o sintoma da decadência de um negócio espalhado por todo o litoral brasileiro e que, em decorrência da expansão da baleação estadunidense e do final do tráfico de escravos, entrava em colapso (Castellucci Junior, 2005).

Assim, enquanto as armações tradicionais faliam em meados do século XIX, Marcos Theodoro Pimentel e José Severo Martins Braga começavam a dominar esse comércio local, envolvendo uma cadeia de sujeitos que, de 
alguma forma, ganhavam dinheiro com os derivados da baleia. Ganhadeiras, fabricantes de cordas, calafates, tanoeiros, arpoadores, remadores, praticamente todos eram libertos e giravam em torno dos negócios controlados por aqueles dois sócios africanos.

Nos anos 1860, tanto Marcos velho como José Severo Martins Braga residiam no centro da vila de Itaparica e, frequentemente, deviam cumprimentar os seus antigos senhores e os descendentes daqueles que um dia os oprimiram. Mas, agora, eles gozavam de prestígio social dado às suas destacadas condições econômicas. E isso passou a fazer a diferença na trajetória de ambos, pois enquanto José, de forma pragmática e solitária, investia em negócios, em imóveis e em escravos, Marcos velho ampliava as suas relações afetivas, investia em imóveis e na baleação, pensando no amparo de parentes, amigos e agregados. Vejamos algumas das suas atitudes.

\section{OS ANOS DE GLÓRIA: NASCEM GALHOS FRONDOSOS}

Em meados da década de 1850, Marcos residia no beco que ligava a Rua dos Patos com a da Glória. À época, já deveria manter algum contato com José Severo Martins Braga, pois residiam bem próximos um do outro. No final dessa década, argumentando o desejo de ter o seu filho perto de si, Marcos resolveu comprar uma casa e presentear o jovem Marcos. Sabe-se que, naqueles anos pós-rebelião malê, conforme a legislação sobre o negro na Bahia, africanos estavam impedidos de adquirir bens de raiz, além de sujeitos a outras restrições.

Será que, ao anunciar o desejo de comprar a casa em nome do filho, Marcos velho pleiteava ludibriar a legislação em vigor? Essa estratégia de aquisição patrimonial foi adotada por outros africanos libertos que viveram na Bahia do século XIX, em período correspondente ao de Marcos (Oliveira, 1979, p.88-89). João José Reis identificou a maneira como o africano Manoel Joaquim Ricardo executou operação semelhante, confessando, ao final da vida, ter comprado imóveis em nome dos seus filhos brasileiros por conta da lei que o impedia de ser proprietário (Reis, 2016, p.45-46).

Mas no caso de Marcos velho, tal procedimento, além de lhe render problema judicial, nos parece revelar outra intenção. Após subsistir aos processos de deportação de africanos e outros dispositivos, só abolidos com a resolução 1.250, de 28 de junho de 1872 (Cunha, 1985; Brito, 2016; Reis, 2016), Marcos reconstruía a sua vida, ampliava o seu círculo de relações afetivas e comprava imóveis, sob os auspícios da legislação contra africanos. 
Em 1859, 6 anos após alforriar o seu filho, Marcos oficiou ao Juiz de órfãos o interesse em adquirir a casa para o seu primogênito. Requereu designação de um curador, "visto ser o suplicante pai natural, e não poder figurar sem nomeação de vossa senhoria". ${ }^{17}$ Como representante legal, Marcos constituiu o professor Belarmino Pereira Pimentel, cujo sobrenome sugere grau de parentesco com os seus antigos senhores, mas não há provas documentais sobre isso. Belarmino morava à Rua dos Patos, vizinho de Marcos velho, e devia conhecê-lo bem. A interlocução com pessoas de influência na esfera política e jurídica de Itaparica o favoreceu no entendimento das coisas, como ocorreu em muitos lugares onde escravos e libertos conseguiam apoio de gente livre para alcançar solução para suas queixas (Grinberg, 2002; Wissenbach, 1998).

Assim, mesmo diante da intransigência do Juiz Municipal e após requerimentos e averiguações, a casa foi comprada. A presunção de que Marcos teria comprado o imóvel em nome do seu filho apenas para se livrar da legislação em vigor não se sustentaria diante de algumas evidências que sugerem outra interpretação. Além de nunca ter mencionado algo sobre a legislação, a casa consta no seu inventário como herança ao seu filho Marcos, e não há sinal de que esta fora questionada pelos demais herdeiros durante a partilha do espólio de Marcos velho.

Ademais, crer na hipótese de que a aquisição de bens envolvendo entes queridos se dava apenas no plano dos interesses materiais e para burlar uma legislação, desconsideraria o peso dos sentimentos afetivos construídos entre pais, mães e filhos africanos durante a escravidão e após a alforria. Marcos velho comprou a alforria do seu filho e jamais exerceu relação de exploração senhorial sobre ele, como ocorrera em outras experiências da escravidão. As suas atitudes indicam sentimentos de afetividade e não interesses meramente materiais.

Nos anos seguintes, Marcos velho aparece ao lado do seu sócio e compadre José Severo Martins Braga, atuando como negociantes da baleação. Os anos 1860 significaram a transição entre a afirmação como africanos libertos e a consolidação como comerciantes, coroada na década seguinte, como importantes empreendedores, donos de armação de baleias e proprietários de casas de aluguel (Castellucci Junior, 2014).

Foi justamente na década de 1860 que Marcos Theodoro Pimentel consagrou sua segunda relação matrimonial, não formalizada pela Igreja, com a africana Raquel. Ela concebeu José Theodoro Pimentel e Flora da Trindade Pimentel, nascidos em 1862 e 1864 respectivamente e que, ao lado de Marcos Cardoso Pimentel, seriam os "únicos e universais herdeiros" dos bens do nagô 
Marcos, conforme o seu testamento. ${ }^{18}$ Treze anos haviam-se passado desde a sua alforria e, considerando a sua carta de liberdade, Marcos velho era um homem de seus aproximados 40 ou 50 anos, embora seja difícil aferir a idade dos africanos deslocados para o Brasil.

À época, o seu sócio, além de imóveis, investiu recursos na aquisição de escravos. Ele possuiu dois cativos e uma "libertanda", todos sepultados no cemitério do Santíssimo Sacramento na década de $1870 .{ }^{19}$ Já Marcos nunca teve escravos e seguiu comprando casas, uma delas na Praça da Quitanda, local privilegiado para as atividades comerciais na vila de Itaparica. Ao fim da vida, Marcos Theodoro Pimentel possuía quatro casas de morada e uma de molhados na vila, animais de carga, uma armação de cozinhar óleo de baleia no Manguinho, embarcações, algum dinheiro em mãos e crédito nas praças comerciais de Itaparica e de Salvador. Essa pequena fortuna era, certamente, resultado dos seus negócios da baleia, embora não constem na documentação escrutinada recibos e outros apontamentos certificando as origens das compras das casas.

Em 1871, ele vendera a seu filho Marcos duas de suas casas na vila de Itaparica, uma situada à Rua da Glória e outra à Rua do Limoeiro, ambas “térreas e precisando de consertos". Vendera praticamente um ano antes da extinção da Lei que vedava a posse de bens por africanos, certamente por isso é que Marcos jovem só oficializaria essa transação bem mais tarde, no ato do inventário e partilha dos bens do seu genitor. Na condição de um dos herdeiros e inventariante do pai, Marcos jovem teve de historiar e descrever os imóveis e produtos dos negócios da baleia legados a ele e seus irmãos.

Ele também precisou explicar a razão pela qual seu pai não o reconhecera como filho legítimo na época em que saiu do cativeiro. Em declarações à justiça, na feitura do inventário, afirmou que seu pai agira assim porque a legislação da época atrapalharia as suas transações no "mesmo negócio de baleias em que eram sócios...”.

A generosidade de Marcos Teodoro para com os seus parentes e pessoas próximas foi flagrante. Constatamos que ele transferia bens aos seus herdeiros à medida que os anos passavam, a maturidade chegava e ele ampliava o patrimônio. Embora não reconhecesse oficialmente Marcos Cardoso como seu filho legítimo, as fontes indicam que Marcos velho construiu uma sólida amizade com o primogênito desde o seu nascimento. À época da venda das casas, Marcos Cardoso tinha 19 anos, e, como sócios na baleação, possuíam uma baleeira em atividade na Baía de Todos os Santos. 
A escravidão seguia o seu curso e, em Itaparica, a quantidade de cativos ainda era considerada na média de importantes cidades baianas, se comparada, por exemplo, com os percentuais relativos à cidade do Salvador. Nos anos 1870, Itaparica contava com uma população de, aproximadamente, 10.120 pessoas. Dessas, cerca de $12 \%$ eram escravos africanos e crioulos, suplantando em aproximadamente $30 \%$ o contingente populacional existente em 1848 , período posterior à chegada de Marcos e José à Ilha. Em 1876, cerca de 4.630 pessoas residiam na vila e nas suas imediações; a maior parte era negra liberta, como os nagô Marcos e José. ${ }^{20}$

Unidos pelo compadrio, pela amizade comercial e afetiva, eles preocupavam-se em ampliar a rede de sociabilidades para amparar amigos egressos do cativeiro. Poucas pistas ficaram para a posteridade do paradeiro da africana Maria Cardoso, do quotidiano dos meninos de Raquel, José Theodoro e Flora da Trindade, no período de ascensão econômica do Marcos velho, ao lado do seu primogênito e de José Severo Martins Braga. Sabe-se que ele cuidava dos dois meninos e de Raquel, além de tocar os negócios da baleia ao lado do seu compadre.

Desde o cativeiro, Marcos foi um africano discreto, enquanto José se destacou por apadrinhar africanos escravizados. Esses diferentes traços de personalidades influenciavam o comportamento de ambos, agora como libertos. José nunca constituiu família e viveu, até a morte, sozinho. Mas isso não o impediu de ser solidário com muitas pessoas próximas a ele, como demonstraram as suas vontades testamentárias. Duas delas reacenderam as fantásticas e duradouras conexões construídas no cativeiro e avivadas na liberdade. Quando formulou o seu testamento, ele "ordenou a Emília, africana minha herdeira que não deite para fora do quarto que ocupa o preto Antonio, e se não cumprir em minha alma sofrerá".

Antonio era um daqueles africanos batizados por ele, com o escravo Agostinho, em primeiro de janeiro de $1834 .{ }^{21}$ Passaram-se 49 anos entre o batismo e o registro de testamento de José, e eles permaneciam conectados. $\mathrm{Na}$ escravidão, ao apadrinhar uma pessoa, em grande parte das vezes, padrinhos assumiam o compromisso de alforriar o afilhado. Também, no fim da vida os mais prósperos davam um mínimo de conforto aos seus protegidos.

José não os esqueceu: deixou também a quantia de 400 mil-réis para libertar outro afilhado que vivia como escravo do Coronel Pinto do Catu, em Santo Amaro do Catu, freguesia na outra extremidade da Ilha e distante da residência de José. Ele se chamava Pedro, batizado em 1820 como escravo do senhor de José, provavelmente vendido àquele senhor posteriormente. ${ }^{22} \mathrm{Tal}$ feito evidencia a manutenção de laços afetivos, mesmo quando o cativeiro 
obrigava o deslocamento de um ente querido para um lugar distante e os padrinhos iam buscá-lo de volta. ${ }^{23}$

Marcos velho também se preocupava com a família e com os desafortunados. Os laços de amizade, as relações comerciais e de compadrio fortaleceram os vínculos entre eles, a família e os camaradas da época de cativeiro. $\mathrm{E}$ ambos se dispuseram, em vários momentos, a socorrer alguém em situação de vulnerabilidade. Uma das provas dessas relações apareceu em 25 de maio de 1883, quando Marcos voltou a enfrentar querelas judiciais. Querendo defender uma africana, por nome Esperança, que respondia a uma ação de despejo da casa em que residia como inquilina, Marcos não só orientou aquela africana sobre a maneira de se defender judicialmente, como também contratou um advogado em Salvador para representá-la.

Foi uma disputa judicial que durou quase 2 anos, chegando até instância superior, onde Marcos foi vencido em seu pleito em 24 de março de 1884. Na ação judicial, não há informações sobre a base legal para Marcos impetrar embargos contra a ação de despejo e pleitear o "sequestro da casa". Não sabemos também das suas intenções, mas algumas evidências processuais sugerem que Marcos mantinha negócios da baleação com a antiga proprietária da casa, a qual era sua vizinha de porta. O que não sabemos é das suas afinidades com a inquilina. ${ }^{24}$

Concluída a disputa pela casa, haviam-se decorrido 6 meses do falecimento do amigo José Severo Martins Braga, morto em 18 de setembro de 1883. Marcos agora era um homem idoso, mas ainda demonstrava disposição para tocar os seus negócios, pois, além da arena jurídica, ele mantinha a baleação na vila de Itaparica e no distrito do Manguinho com seu filho Marcos Cardoso Pimentel.

A maior evidência de cumplicidade entre os dois Marcos, pai e filho, foi certamente a grande viagem espiritual que fizeram juntos a Lagos, em maio de 1881 (Castillo, 2010, p.17). Foi importante, dentre outros aspectos, para que eles trouxessem o assento de Babá Olukotum, ancestral legendário dos povos iorubás, cultuado até hoje nos terreiros de Babá Egum da Bahia, como registrou Lisa Castillo (Castillo, 2012, p.108). Observando a lista dos africanos libertos que viajaram, duas coisas surpreendem. Praticamente silenciada na documentação escrutinada, a primeira mulher de Marcos velho desapareceu dessa trama histórica. Porém, quando o navio a vapor zarpou da Bahia, rumo à cidade de Lagos, levando os dois Marcos, constava na lista de passageiros, logo acima do nome Marcos Pimentel, uma senhora, cujo nome era Maria Theodoro Cardoso, africana liberta. Talvez seja esse o único registro que temos da mãe de Marcos jovem e, se essa evidência estiver correta, suspeitamos de que ela não tenha retornado ao Brasil após $1881 .{ }^{25}$ Isso explicaria, em parte, a 
atitude de Marcos velho de não a ter relacionado como meeira dos seus bens, junto aos demais legatários.

Registrado naquela importante documentação ao lado de seu núcleo familiar, por que o nome de Maria Cardoso também se apagou da memória oral dos seus descendentes? Seria uma maneira de os familiares evitarem falar da relação simultânea de Marcos velho com Maria e com Raquel? Afinal, à época da viagem, lembremos, as fontes informam que ele vivia com Raquel e seus filhos. No seu universo sociocultural, esse tipo de relação não era censurável, uma vez que na tradição iorubá, ter várias mulheres era sinônimo de prestígio e riqueza (Castillo, 2012, p.67). Como nagô e homem de posses, senhor das armações de baleias, tal status sugeriria importância simbólica para o liberto Marcos.

Embora ausente da lista dos embarcados, não resta dúvidas de que Marcos jovem esteve presente naquela viagem. Não sabemos se erros nos registros de passageiros ou se extravio de documentos podem ter eliminado o seu nome das listas dos viajantes. Porém, tanto a tradição oral quanto o seu pedido de passaporte, expedido pela Secretaria de Polícia com o do pai, em 1881, chancelam nossa tese (Castillo, 2010). ${ }^{26}$

Talvez, nunca saibamos o destino da africana Raquel e da filha de Marcos velho, Flora da Trindade Pimentel, pois praticamente inexistem registros de ambas em toda a documentação escrutinada. Uma saída seria o recurso da tradição oral dos seus descendentes, por serem as mulheres exaltadas nessas recordações, enquanto os homens são quase esquecidos. Depoimentos orais de familiares têm sido colhidos. Entretanto, em nenhum deles houve explicações a respeito do destino dessas duas senhoras e, menos ainda, de Maria Cardoso.

Ao falecer, em 3 de julho de 1886, Marcos Theodoro Pimentel, o Obaráyì (Mariano; Queiroz, 2009), ${ }^{27}$ deixaria para os filhos e para Raquel, além de pequena fortuna, um incrível legado religioso, lições de solidariedade, de afirmação da identidade por meio da linhagem forjada pela perpetuação dos seus sobrenomes e consolidação dos laços de parentesco. Dois dos seus filhos se encarregariam de continuar a sua obra pelo século XX.

\section{LAGOS, LEGADOS E MEMÓRIA}

Do mar da Baía de Todos os Santos Marcos Theodoro Pimentel retirou baleias, e dos seus derivados fez relativa fortuna. É prudente compararmos, por exemplo, a sua riqueza com os padrões de prosperidade de dois africanos 
bem-sucedidos que viveram na Bahia oitocentista, e que têm sido estudados por um importante historiador baiano. Vivendo na cidade do Salvador, o africano Manoel Joaquim Ricardo, quando faleceu, em 1865, deixou um patrimônio aquilatado em 42 contos de réis, o que lhe conferia o status de membro do seleto grupo dos 10\% mais ricos da elite soteropolitana oitocentista (Reis, 2016, p.3).

Já Domingos Sodré, morto no ano de 1887, data próxima do passamento de Marcos, embora tivesse adquirido bens valorizados no curso da vida, ao ser sepultado deixou para a esposa o espólio avaliado em um conto e 110 mil-réis, que, depois de deduzidas as despesas, reduziram-se a apenas 336.779 réis (Reis, 2006, p.306). Assim, com base nesses dois casos, poderíamos considerar que Marcos não era riquíssimo, aos olhos do que representou Manoel Ricardo.

À semelhança do sacerdote Sodré, Marcos foi um liberto pouco remediado, que possuía o suficiente para viver de modo relativamente confortável. Ainda assim, considerando a média patrimonial da maioria dos libertos que viveram em Itaparica no tempo de Marcos e que, de alguma forma, ascenderam economicamente, certamente Marcos Theodoro Pimentel, com patrimônio avaliado em 1:749\$000 réis, foi um africano rico e destacado em seu mundo insular.

Ao partir para Lagos, na África, e sabendo que se aproximava o momento da sua passagem para outra dimensão, Marcos deu um grande passo na direção de eternizar a sua linhagem quando fundou em Itaparica o mais importante terreiro de culto aos eguns, no distrito de Amoreira, na fazenda Tuntum (Braga, 1992). Ele tinha consciência de haver cumprido a sua missão e agora deixava o legado religioso.

Para os que professam o culto aos eguns, o patriarca religioso não morreu, apenas passou a viver espiritualmente entre os seus, pois sem os seus ancestrais a humanidade não existiria. Como disse Juana Elbein, os eguns são criadores simbólicos e espirituais, ancestrais divinos de uma família (Santos, 2008, p.102104). Como um baobá, árvore sagrada africana que pode chegar a 20 metros de diâmetro, viver por até 6 mil anos e armazenar grande quantidade de água, Marcos fincou raízes profundas em Itaparica e de lá ramificou os seus galhos frondosos para outros locais do Brasil no curso do século XX.

Os seus filhos, Marcos Cardoso Pimentel e José Theodoro Pimentel, deram continuidade ao culto nagô e figuraram como homens de respeito e influência na cidade de Itaparica. Ambos seguiriam a vida como comerciantes, donos de casas de aluguel e proprietários da fazenda Tuntum, onde o culto era realizado, tendo sido transferido, posteriormente, para Ponta de Areia, e atualmente segue na localidade do Barro Vermelho (Sant'Anna Sobrinho, 2015). 
Seu primogênito viveu por aproximadamente 85 anos, embora conste na declaração de óbito que teria morrido aos 103 anos. Morto em 19 de outubro de 1937, Marcos jovem residia numa casa à Rua Carneiro Ribeiro, em Itaparica, não teve filhos e era casado com Rufina Suzana Pimentel, falecida em 7 de fevereiro de 1944, aos 68 anos. Quando se casaram, Marcos jovem era um velho calafate de seus 75 anos, e Rufina, uma viúva, doméstica de 55 anos. ${ }^{28}$

Como legado, ele deixou ao herdeiro, um sobrinho da sua esposa, a casa e parte da fazenda Tuntum, distante cerca de 2,5 quilômetros da cidade de Itaparica; bens herdados de seu pai. Assim como Marcos velho, o jovem Marcos foi uma figura discreta, talvez fruto da intensa relação vivida com o seu genitor, quando compartilharam os negócios da baleação e a incrível viagem a Lagos. Sua personalidade, porém, nunca foi empecilho para o estreito vínculo de amizade firmada com seu meio-irmão, José Theodoro Pimentel.

O filho legítimo de Raquel Maria da Conceição, bem mais jovem do que Marcos, seria, no curso da primeira metade do século XX, consagrado como ícone dos Pimentel. À época, José Theodoro Pimentel já estava casado, era homem de negócios, ostentava título de capitão, era membro da Irmandade do Santíssimo Sacramento, possuía sete casas de aluguel em Itaparica e morava na Praça da Botica, na famosa casa deixada por seu pai. Quando sua primeira esposa, Saturnina Valéria Pimentel, faleceu, em 27 de fevereiro de 1922, aos 47 anos, sua única filha, Ondina Valéria Pimentel, tinha apenas 6 anos. ${ }^{29}$

Mais tarde, José Theodoro Pimentel contrairia outro matrimônio, apenas no religioso, segundo o seu testamento, com Maria José Evangelista Pimentel, filha da africana Maria Evangelista do Socorro. Assim como fizera seu pai, José também manteve a tradição de casamento entre africanos e descendentes. Dessas núpcias nasceram os filhos: Orlando Pimentel, Antonio Pimentel e Joana Maria Pimentel, além de um filho adotivo, Argemiro Pimentel.

Além de cuidar dos negócios onde nascera e fora criado, José Theodoro também mantinha, com Marcos Cardoso, os afazeres na fazenda Tuntum. Ocupou o cargo de Balé Xangô no Axé Opô Afonjá, sucedendo a Bamboxê Obitikô, lendário africano liberto que, ao lado de Joaquim Vieira da Silva e Aninha, teve importante participação na fundação daquele candomblé em 1910 (Castillo, 2012, p.107). Durante esse tempo, José Theodoro assessorou Aninha e, em 1921, sua filha carnal, Ondina Valéria Pimentel, foi iniciada por aquela sacerdotisa, prenúncio do que o futuro lhe reservava. $O$ vínculo da família Pimentel com a primeira sacerdotisa do Axé Opô Afonjá sugere que quando Marcos velho e Marcos jovem estiveram em Lagos, tenham feito contatos com Bamboxê e Martiniano Bonfim, babalaô que também fez parte da 
comunidade de negros libertos em Lagos no século XIX e que, após participar da fundação do Terreiro da Casa Branca, migrou para formar o Ilê Axé Opô Afonjá.

Quando José Theodoro faleceu em 21 de novembro de 1938, aos 77 anos, vítima de esclerose cardiorrenal, Ondina Valéria Pimentel era maior de 21 anos, morava no Largo de Santana, bairro do Rio Vermelho, em Salvador, e sua meia-irmã, Joana Maria Pimentel, tinha apenas 2 anos. O destaque das duas filhas de José é emblemático nessa trama histórica porque aqui há curiosa inversão de um processo histórico. Se, no passado, as mulheres e a filha de Marcos velho desapareceram das fontes documentais, aqui foram os filhos de José que nos deixaram pouquíssimos rastros, enquanto as suas duas filhas ganharam protagonismo.

Preocupado em amparar os filhos, José Theodoro fez testamento, e nele foram registradas importantes declarações. ${ }^{30}$ Coube a Ondina Valéria Pimentel e à segunda esposa de José Theodoro o inventário dos bens e encaminhamento dos funerais. Com seu passamento fechava-se um ciclo e abria-se outro, pois é assim que reza a tradição do candomblé de vertente nagô (Santos, 2008). Ao lado do seu irmão, Marcos Cardoso Pimentel, José Theodoro chefiou o culto aos egunguns, e no Tuntum iniciaram Mestre Didi quando este tinha 8 anos, tornando-se desde então amigo inseparável de Ondina Pimentel e sucessor de seu pai na chefia da casa de Xangô (Ayoh'Omidire, 2005, p.259; Cajé, 2017, p.14).

Ubaldo Osório Pimentel, historiador itaparicano, avô materno do escritor João Ubaldo Ribeiro, conheceu os irmãos José e Marcos Pimentel quando possuía uma propriedade fronteiriça à fazenda Tuntum, território dos babás egunguns. Em seu livro de história da Ilha ele relata a época em que o terreiro era chefiado pelos famosos irmãos (Osório, 1979). Por conta desses e de outros episódios é que, diferentemente do baobá, símbolo do esquecimento, Marcos e José jamais foram esquecidos na memória dos habitantes de Itaparica.

E, como memória é a arte da guerra das imagens, disputa pela recordação, conflito entre o que deve ser esquecido e o lembrado, aqui, a memória da família Pimentel se impôs ante a tradição e a ostentação dos traficantes de escravizados. Como se fosse uma guerra por lugares, pode-se observar, ainda nos dias de hoje, em uma das paredes internas da Igreja Matriz do Santíssimo Sacramento, a cripta de um traficante de escravizados que viveu e morreu em Itaparica. Do lado oposto, quase frontal à Matriz, como que o desafiando, ergueu-se a igreja de São Lourenço. No centro da nave, local de sepultamento daqueles que gozavam de grande prestígio social, encontra-se uma lápide com esta gravação: 


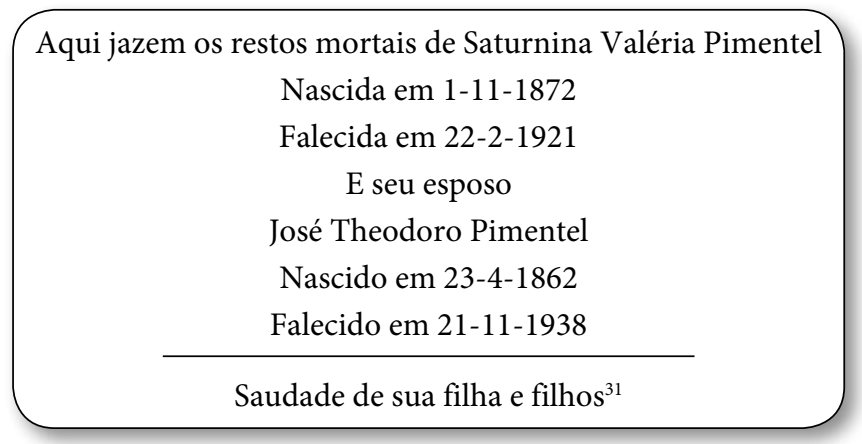

A cerca de 500 metros dali, sentada à frente de uma casa de porta e duas janelas, na Praça Tenente Botas, encontra-se uma senhora conhecida carinhosamente por dona Joaninha. Muitas das pessoas que por ali transitam não têm a mínima ideia da relação entre aquela simpática senhora e a lápide assentada no centro da nave do templo de São Lourenço. Seu nome completo é Joana Maria Pimentel, aquela garota que tinha apenas 2 anos quando seu pai, José Theodoro Pimentel, faleceu. A casa em que ela reside é a mesma que foi comprada pelo africano Marcos velho, nos anos 1860, e era usada como ponto comercial.

Portanto, quando Ondina Valéria Pimentel ascendeu como sacerdotisa do Ilê Axé Opô Afonjá, ela já carregava uma herança cultural e religiosa e grande reputação, assim como havia acumulado uma experiência incrível na sua trajetória como líder espiritual ao lado de Deoscóredes Maximiliano dos Santos (Mestre Didi), morto em 2013. Sem sombra de dúvidas, os seus caminhos foram abertos pelo patriarca Marcos, seguido pelos seus filhos e, finalmente, por Ondina Pimentel, formada em música e professora de piano, que se impôs como destacada descendente de uma das mais extraordinárias linhagens de africanos nagôs em terras brasileiras.

\section{REFERÊNCIAS}

AYOH'OMIDIRE, Félix. Yorubanidade mundializada: o reinado da oralitura em textos yorubá-nigerianos e afro-baianos contemporâneos. Tese (Doutorado) - Programa de Pós-Graduação em Letras e Linguística, Universidade Federal da Bahia (UFBA). Salvador, 2005.

BRAGA, Júlio. Ancestralidade afro-brasileira: o culto de Babá Egum. 2.ed. Salvador: Ed. UFBA, 1992. 
BRAGA, Júlio. Na gamela do feitiço: repressão e resistência no candomblé. Salvador: Ed. UFBA, 1995.

BRITO, Luciana da Cruz. Temores da África: segurança, legislação e população africana na Bahia oitocentista. Salvador: Ed. UFBA, 2016.

CAJÉ, Antonio Marcos dos S. Um olhar epistemológico nos contos afro-brasileiros de Mestre DiDi. Dissertação (Mestrado em História) - Mestrado Profissional em História da África, da Diáspora e dos Povos Indígenas, Universidade Federal do Recôncavo da Bahia (UFRB). Cachoeira, 2017.

CARNEIRO, Edson. Candomblé da Bahia. Rio de Janeiro: Civilização Brasileira, 1986.

CASTELLUCCI JUNIOR, Wellington. De cativos a baleeiros: uma amizade indissolúvel entre dois africanos no outro lado do Atlântico (Itaparica, 1816-1886). Topoi, Rio de Janeiro, v.15, n.29, p.444-472, jun./dez. 2014.

. Pescadores e baleeiros: o envolvimento de escravos e forros na atividade da pesca da baleia nas últimas décadas do oitocentos. Itaparica: 1860-1888. Afro-Ásia, Salvador: CEAO/UFBA, v.33, p.133-168, 2005.

CASTILLO, Lisa Earl. Em busca dos agudás da Bahia: trajetórias individuais e mudanças demográficas no século XIX. Afro-Ásia, Salvador: CEAO/UFBA, n.55, p.111147, 2016.

. Entre memória, mito e História. Viajantes transatlânticos da Casa Branca. In: REIS, João José; AZEVEDO, Elciene (Org.) Escravidão e suas sombras. Salvador: Ed. UFBA, 2012.

. Entre a oralidade e a escrita: a etnografia nos candomblés da Bahia. Salvador: Ed. UFBA, 2010.

. O terreiro do Gantois: redes sociais e etnografia histórica no século XIX. Revista História (USP), São Paulo, n.176, p.1-57, 2017.

CHALHOUB, Sidney. A força da escravidão: ilegalidade e costume no Brasil oitocentista. São Paulo: Companhia das Letras, 2012.

CONRAD, Robert. Os últimos anos de escravatura no Brasil. 2.ed. Rio de Janeiro: Civilização Brasileira, 1978.

COSTA LIMA, Vivaldo da. O candomblé da Bahia na década de 1930. Revista Estudos Avançados, São Paulo, v.18, n.52, p.201-221, 2004.

. O conceito de "nação" nos candomblés da Bahia. In: COLÓQUIO NEGRITUDE ET AMÉRIQUE LATINE, Dacar: Governo do Senegal; Unesco, 7-15 jan. 1974. Publicado em: Afro-Ásia, Salvador: CEAO/UFBA, n.12, p.65-90, 1976. Disponível em: https://portalseer.ufba.br/index.php/afroasia/article/view/20774/13377; acesso em: 29 out. 2017.

. A família de Santo nos candomblés Jejes-Nagôs da Bahia. 2.ed. Salvador: Corrupio, 2003. 
CUNHA, Manuela Carneiro da. Nem cidadãos nem estrangeiros: os africanos libertos. In: . Negros estrangeiros: os escravos libertos e a sua volta à África. São Paulo: Brasiliense, 1985.

FERREIRA, Roberto Guedes. Parentesco, escravidão e liberdade (Porto Feliz, São Paulo, século XIX). Varia História, Belo Horizonte: UFMG, v.27, n.45, p.233-263, jan./ jun. 2011.

FLORENCE, Afonso Bandeira. Nem escravos, nem libertos: os 'africanos livres' na Bahia. Caderno CEAS, Salvador, n.121, p.58-71, 1989.

GRINBERG, Keila. O fiador dos brasileiros: cidadania, escravidão e direito civil no tempo de Antonio Pereira Rebouças. Rio de Janeiro: Civilização Brasileira, 2002.

JEHA, Silvana. Ganhar a vida: uma história do barbeiro africano Antônio José Dutra e sua família. Rio de Janeiro, século XIX. Revista de História (USP), São Paulo, n.176, p.1-35, 2017.

LUZ, Marco Aurélio. Do tronco ao Opa Exim. Rio de Janeiro: Pallas, 2002.

MAMIGONIAN, Beatriz Gallotti. Os direitos dos libertos africanos no Brasil oitocentista: entre razões de direito e considerações políticas. Revista de História (USP), São Paulo, v.34, n.2, p.181-205, jul./dez. 2015.

MARIANO, Agnes; QUEIROZ, Aline. Obaràyí - Babalorixá Balbino Daniel de Paula. Salvador: Barabô, 2009.

MATTOSO, Katia M. de Queiroz et al. Notas sobre as tendências e padrões de preços de alforria na Bahia, 1819-1888. In: REIS, João José (Org.) Escravidão e invenção da Liberdade: estudos sobre o negro no Brasil. São Paulo: Brasiliense; CNPq, 1988. p.60-72.

OLIVEIRA, Maria Inês C. de. O liberto e os outros: Salvador, 1790-1890. Dissertação (Mestrado em Ciências Sociais) - Universidade Federal da Bahia (UFBA). Salvador, 1979.

OSÓRIO, Ubaldo. A Ilha de Itaparica: história e tradição. 4.ed. Salvador: Fundação Cultural do Estado da Bahia, 1979.

PARĖS, Luís Nicolau. A formação do Candomblé: história e ritual da nação Jeje na Bahia. Campinas: Ed. Unicamp, 2006.

. Milicianos, barbeiros e traficantes numa irmandade católica de africanos minas e jejes: Bahia, 1770-1830. Revista Tempo, Rio de Janeiro, v.20, p.1-32, 2014. PIMENTA, Tânia Salgado. Barbeiros-sangradores e curandeiros no Brasil (1808-1828). História, Ciências, Saúde - Manguinhos, Rio de Janeiro, v.5, n.2, p.349-375, 1998.

REIS, João José. Domingos Sodré: um sacerdote africano na Bahia oitocentista. Revista Afro-Ásia, Salvador: CEAO/UFBA, n.34, p.237-313, 2006.

De escravo a rico liberto: a trajetória do africano Manoel Joaquim Ricardo na Bahia oitocentista. Revista de História (USP), São Paulo, n.174, p.15-68, jan./ jun. 2016. 
REIS, João José. Há duzentos anos: a revolta escrava de 1814 na Bahia. Topoi, Rio de Janeiro, v.15, n.28, p.68-115, jan./jun. 2014.

RODRIGUES, Jaime. O infame comércio: propostas e experiências no final do tráfico de africanos para o Brasil (1800-1850). Campinas: Ed. Unicamp, 2000.

SANT'ANNA SOBRINHO, José. Terreiros Egúngún: um culto ancestral afro-brasileiro. Salvador: Ed. UFBA, 2015.

SANTOS, Deoscóredes Maximiliano dos. História de um terreiro Nagô. São Paulo: Max Limonad, 1988.

SANTOS, Juana Elbein dos. Os nagô e a morte. 13.ed. Petrópolis: Vozes, 2008.

WISSENBACH, Maria Cristina C. Sonhos africanos, vivências ladinas: escravos e forros em São Paulo (1850-1880). São Paulo: Hucitec, 1998.

\section{NOTAS}

${ }^{1}$ Jornal da Bahia, 20 mar. 1975. Matéria: "Mãe Ondina morre e silencia terreiros". Disponível em: http://ceao.phl.ufba.br/phl8/popups/1975-03-20_r1.pdf; acesso em: 25 out. 2017.

${ }^{2}$ ACMS - Arquivo da Cúria Metropolitana de Salvador (LEV - Laboratório de Restauro Eugênio Veiga). Batismo de Marcos. Livro de Batismos da Paróquia do Sacramento de Itaparica (1815-1840); imagem 91, p.61. Disponível em: https://www.familysearch.org/ ark:/61903/3:1:9392-8565-Q?i=90\&wc=M7ZY-FPJ33A370070401\%2C370070402\%2C370 070403\%3Fcc\%3D2177272\&cc=2177272; acesso em: 16 maio 2018.

${ }^{3}$ ACMS - Arquivo da Cúria Metropolitana de Salvador (LEV - Laboratório de Restauro Eugênio Veiga). Livro de Batismo da Paróquia do Sacramento de Itaparica. Disponível em: https://www.familysearch.org; acesso em: 27 nov. 2017.

${ }^{4}$ Viagens de Isidoro Martins Braga. Disponível em: http://www.slavevoyages.org/voyage/ search; acesso em: 27 nov. 2017.

${ }^{5}$ APB - Seção judiciária - Quadro numérico da população livre de 14 municípios desta Província da Bahia. Secretaria de Polícia da Bahia, 16 fev. 1848.

${ }^{6}$ APB - Seção Colonial/Provincial. Governo da província - judiciário, escravos (assuntos). 1825-1887. M.2896.

${ }^{7}$ APB - Tribunal de Justiça - Apreensão. O comandante da escuna relâmpago. Itaparica, 1851. 05/167/06/1249. Documentação indisponível.

${ }^{8}$ ACMS - Arquivo da Cúria Metropolitana de Salvador (LEV - Laboratório de Restauro Eugênio Veiga). Livro de Batismos da Paróquia do Sacramento de Itaparica (1840-1862); imagem 40, p.38. Batizado dos africanos da armação de baleia pertencente a Francisco Baldoíno Ferreira e Francisco Antonio Ferreira. Itaparica, 1 out. 1847. Disponível em: https://www.familysearch.org/ark:/61903/3:1:9392-85NB-Q?i=39\&wc=M7ZY-YTR\%3A3 70070401\%2C370070402\%2C370103001\&cc=2177272; acesso em: 26 fev. 2018. 
${ }^{9}$ O Alabama, 20 jan. 1866. Disponível em: http://200.187.16.144:8080/jspui/bitstream/ bv2julho/987/12/Janeiro_1866.pdf; acesso em: 28 fev. 2018.

${ }^{10}$ APB - Seção Colonial/Provincial. Inventário do africano Marcos Theodoro Pimentel. Itaparica, 1886. DOC: 05/2066/2537/08. Em anexo, Carta de Liberdade de Marcos.

${ }^{11}$ Em contagem de aproximadamente 100 escravos avaliados em inventários, que compraram as suas alforrias nas décadas de 1850 e 1860 em Itaparica, os valores oscilaram entre $\$ 1: 000,000$ e $\$ 1: 500,000$. Nas décadas seguintes os valores recuaram para os patamares de \$800:000 e \$600:000.

${ }^{12}$ APB - Seção Judiciária, Tribunal da Relação. Petição para manutenção. Autor: Pedro, africano. Itaparica, 1859. Doc: 34/1195/20.

${ }^{13}$ APB - Seção Judiciária. Polícia. Maço 6347. Doc: 185328/02. Carta de liberdade de Marcos Cardoso Pimentel. Itaparica, 1853. Ver também, Arquivo da Cúria Metropolitana de Salvador, filme 128-4581, item 5. Batizado/Itaparica, 1840-62, f.94.

${ }^{14}$ ACMS - Arquivo da Cúria Metropolitana de Salvador (LEV - Laboratório de Restauro Eugênio Veiga). Batismo de Marcos Jovem. Livro de Batismo de Itaparica (1840-1862); imagem 96, p.24. Disponível em: https://www.familysearch.org/ark:/61903/3:1:9392-85NJ$-\mathrm{S} ? \mathrm{i}=95 \& \mathrm{wc}=\mathrm{M} 7 \mathrm{ZY}-\mathrm{YTR} \% 3 \mathrm{~A} 370070401 \% 2 \mathrm{C} 370070402 \% 2 \mathrm{C} 370103001 \& \mathrm{cc}=2177272$; acesso em: 26 fev. 2018.

${ }^{15}$ ACMS - Arquivo da Cúria Metropolitana de Salvador (LEV - Laboratório de Restauro Eugênio Veiga). Livro de batismos da Freguesia do Sacramento de Itaparica, Livro B, (1815-1840), n.1, f.5. Batizado de José. Disponível em: https://www.familysearch.org/ ark:/61903/3:1:9392-856T-H?i=4\&wc=M97Y-L5\%3A24182851.\&cc=2177272; acesso em: 26 fev. 2018.

${ }^{16}$ ACMS - Arquivo da Cúria Metropolitana de Salvador (LEV - Laboratório de Restauro Eugênio Veiga). Batizado de Flora. Livro de batismo de Itaparica (1862-1869); imagem 98, p.95. Disponível em: https://www.familysearch.org/ark:/61903/3:1:9392-8PNH-1 ? $\mathrm{i}=97 \& w c=M 7 Z B-W 2 Q \% 3 A 370070401 \% 2 C 370070402 \% 2 C 370123701 \& c c=2177272$; acesso em: 28 fev. 2018.

${ }^{17}$ APB - Seção Judiciária. Requerimento 52. Marcos Theodoro Pimentel. Classificação: 34/1195/1. Itaparica, 1859.

${ }^{18}$ APB - Seção judiciária. Testamento de Marcos Theodoro Pimentel. Itaparica, 1886. 05/2066/2537/08.

${ }^{19}$ ACMCS - Arquivo da Cúria Metropolitana do Salvador (LEV - Laboratório de Restauro Eugênio Veiga). Livro de assentos de óbitos da Matriz do Santíssimo Sacramento de Itaparica (1816-1882), p.65, 75, 88.

${ }^{20}$ APB - Mapa Estatístico da Província da Bahia. 1876.

${ }^{21}$ ACMS - Arquivo da Cúria Metropolitana de Salvador (LEV - Laboratório de Restauro Eugênio Veiga). Livro de batismos da Freguesia do Sacramento de Itaparica, Livro B, 
(1815-1840), nº1, fs.70 e 71. Disponível em: https://familysearch.org/pal:/MM9.3.1/TH1-18354-12815-23?cc=2177272\&wc=M97Y-PL5:24182851; acesso em: 20 jan. 2014.

${ }^{22}$ ACMS - Arquivo da Cúria Metropolitana de Salvador (LEV - Laboratório de Restauro Eugênio Veiga). Batismo do africano Pedro. Livro de Batismos da Freguesia do Sacramento de Itaparica (1815-1840); imagem: 15, livro sem numeração. Disponível em: https:// www.familysearch.org/ark:/61903/3:1:9392-85XL-P?i=14\&wc=M7ZY-FPJ\%3A370070401 \%2C370070402\%2C370070403\&cc=2177272; acesso em: 28 fev. 2018.

${ }^{23}$ APB - Seção Colonial/Provincial. Carta de liberdade do escravo Pedro, anexa ao Inventário de José Severo Martins Braga. Itaparica, 1883. Doc: 04/1544/2013/16.

${ }^{24}$ APB - Ação de despejo - Seção Judiciária. Itaparica, 1883/1884. Doc: 45/1606/19.

${ }^{25}$ APB - Livros de Entrada e Saída de Passageiros no porto de Salvador (Bahia) - 18551964. Relação dos livros da Inspetoria da Polícia do porto de Saída de Passageiros. Relação dos africanos que embarcaram na Bahia para Lagos, na África. Salvador-BA, $1^{\circ}$ nov. 1881. Brasil, Bahia, Relações de passageiros e imigrantes, 1855-1964. Livro 3 (1879-1883); imagem 233. Disponível em: https://www.familysearch.org/ark:/61903/3:1:3QS7-892YQS62?i=232\&wc=S9B8-L2S\%3A1294021102\&cc=1928179; acesso em: 26 fev. 2018.

${ }^{26}$ APB - Polícia. Pedido de Passaporte do crioulo liberto Marcos, 14/05/1881. Escravos, 1881-1885, maço: 6347; Entrada de passageiros (1879-1883), v.3.

${ }^{27}$ Nome iniciático de Marcos no Candomblé, semelhante ao de outro do pai de santo de Itaparica, Balbino Daniel de Paula, que, por ter a mesma qualidade de Xangô de Marcos Teodoro, ostenta também o nome de Obaraín.

${ }^{28}$ APB - Seção Judiciária, inventário de Marcos (Theodoro) Cardoso Pimentel. Itaparica, 30/10/1945. Doc: 02/756/1222/07.

${ }^{29}$ APB - Seção Judiciária, Inventário de Saturnina Valéria Pimentel. Itaparica, 1922. DOC: 02/616/1070/09.

${ }^{30}$ APB - Seção Colonial/Provincial. Testamento/Inventário de José Theodoro Pimentel. Itaparica, 1939-1952. Doc: 02/682/1142/04.

${ }^{31}$ Registro na lápide no centro da nave da Igreja de São Lourenço, cidade de Itaparica.

Artigo recebido em 19 de dezembro de 2017.

Aprovado em 15 de maio de 2018. 